\title{
The World Social Forum and the Challenges of Global Democracy
}

Jackie Smith

Sociology Department, State University of New York at Stony Brook

Published in Global Networks 4(3) October 2004 www.Blackwell-

Synergy.com/links/toc/glob

\begin{abstract}
Protests against economic globalization helped give birth to the World Social Forum (WSF) as a space for civil society groups to coordinate actions and articulate shared visions for global change. Since 2001 the WSF has brought together hundreds of thousands of activists from all parts of the world. But creating an inclusive political space that is also effective at generating unified action has proved challenging. This article explores the central tensions in the 2004 WSF and explores the possibilities for the Forum to overcome these obstacles and expand global democracy.
\end{abstract}

Last February 15, 2003, an estimated 12 million protesters gathered in over 700 cities in 60 countries to protest U.S. plans to invade Iraq. In many major cities, these protests were the largest ever recorded. Even in New York City, still reeling from the emotional repercussions of 9/11, tens of thousands of protesters gathered along First Avenue on a frigid Saturday. A planned protest march was banned by the city-- under pressure from the Federal government-- and police kept thousands of protesters from even reaching First Avenue.

To many, such a globally coordinated protest may seem unremarkable. Indeed, such events have been with us since the 1880s when the Socialist International campaign for an 8-hour workday made May 1 a "global day of action" (see, e.g., Nimtz 2002). And more recently, groups like People's Global Action have used the Internet to call for global days of action against the world's financial institutions, with "N-30" (i.e., the November 30 start of the Seattle WTO meeting in 1999) among the more prominent of these.

Nevertheless, from an organizer's perspective, the February 15 protests were an amazing achievement. For one, there was no pre-planned inter-governmental meeting around which to focus the event's timing and agenda. The date of the event was arbitrary, and the staging of demonstrations outside the United States and Britain might have had some symbolic significance, but it made rather little strategic sense. Convincing activists to devote the immense energies required to pull off a last-minute call for massive demonstrations would not be an easy task in most situations. But somehow the February 15 global day of action was so successful that a New York Times column referred to global public opinion as the "second superpower" (Benjamin 2004). While the world's governments working together could not dissuade the U.S. from its plans for war, the world's people, acting together, further undermined the legitimacy of Bush's actions. 
Last year's global anti-war protests were possible because of the foundations laid by the global justice movement. The idea for a global day of action and early planning for the event took place in Porto Alegre, Brazil, during the third meeting of what has become an annual "World Social Forum." Mobilizing around the slogan that "Another World is Possible," the World Social Forum (WSF) began as both a protest against the annual World Economic Forum in Davos, Switzerland and as a response to critics' arguments that "we know what you're against, but what are you for?"

The wars of the Bush administration clearly have forced global justice activists to reframe their struggle, and the USA PATRIOT Act and its international counterparts pose new challenges to mobilizing any form of dissent. But the persistence and growth of the WSF belies the notion that wars have again displaced transnational opposition to economic globalization. In fact, while the Second Socialist International crumbled in the face of world war and the nationalist fervor accompanying it, the WSF signals new hope that transnational solidarity might overcome nationalist divisions in wartime.

\section{Origins \& Development of the World Social Forums}

Although the "World Social Forum" began officially in January of 2001, many key organizers place its origins in 1996 at the First International Encuentro for Humanity and Against Neoliberalism. The encuentro is a model for dialogue and exchange that is familiar to Latin American activists; one that gained wide international attention when the Zapatistas called for the 1996 meeting as part of their efforts to expand their own struggle against the global sources of their grievances. Although the size of the WSF which grew from around 10,000 participants in 2001 to more than 100,000 in the past two years - prevents much of the intimate exchange and consensus-building that "encuentro" implies - it remains true to its purpose as an "open space" for activists to gather, exchange experiences, support each other's struggles, build transnational alliances, and plan coordinated strategies and actions.

The WSF explicitly rejects a representative role, and it makes no recommendations or formal statements on behalf of participants. It does require that participants adopt a general opposition to neoliberal globalization and a commitment to nonviolent struggle. These basic principles have allowed it to include many voices while avoiding major divisions and hierarchies, but recent experiences suggest that the WSF might be outgrowing this organizing formula.

The first Forum was largely an "anti-Davos" people's assembly. The second WSF encouraged more explicit searches for alternatives to neoliberal globalization, and subsequent meetings have sought to articulate concrete steps towards achieving these alternatives. The International Council (IC)--which attempts to bring representative leadership to the WSF while insuring its continuity and basic principles-is plagued by the constant tensions between the demands of organizing annual meetings for 100,000 while maintaining inclusive and decentralized decision making structures. It includes a wide range of organizations, and organizers explicitly seek to avoid exclusionary tendencies and to maximize space for expressions of diversity. No doubt there will 
always be room for improvement here. Thus, the past two meetings saw extensive critical self- reflection by participants on the WSF as both a structure and process. The move to India this year reflects this tendency to some extent, as participants are well aware of how the location of a meeting determines who can participate, and it privileges some voices over others. Following its first tentative foray outside of Brazil's Worker Party haven of Porto Alegre, the IC is now seeking a feasible site in Africa for 2006.

The diversity of voices in the WSF process has also been expanded by the proliferation of local, national and regional Social Forums. The main web site for the WSF lists links to at least nine national social forums in Europe, Latin America, Quebec, as well as a Palestinian social forum. Regional forums have met (or will soon meet) in Europe, Africa, Asia, and the Americas, and there are Forums for the Mediterranean and Pan Amazonian regions. In addition, numerous cities have hosted social forums to bring together a broad range of local activists who are increasingly aware of the global sources and the interconnectedness of the problems on which they work.

The most active region is in Europe, which drew an estimated 60,000 activists to its first forum in 2002, and which plans a second forum in Britain in 2004. Africa remains the least active in the WSF process, although organizers there note the growth in African delegations in successive Social Forums, and they anticipate that hosting the WSF in 2006 will assist them in their regional organizing efforts. American activists have been notably scarce both at the WSF itself and in terms of regional organizing. Nevertheless, there have been limited and thus far unsuccessful attempts to mobilize a North American forum, and several U.S. cities have been sites of local social forums.

\section{WSF-Mumbai, 2004 ${ }^{1}$}

The move to Mumbai this year represents a milestone for the WSF. This year's meeting proves that the event can survive outside of its incubator, the nurturing and supportive political space of Porto Alegre. It also expands the political base of the Forum. The move to India provided new opportunities for regional cooperation around WSF themes and provided an organizing rationale for the Asian Social Forum in November. It also very likely will both motivate and provide a template for African organizers to plan their turn as hosts to the WSF.

The style of the 2004 WSF was markedly different from that of the Porto Alegre forums. The Indian organizing team succeeded in attracting more popular, grassroots movements than were seen in Porto Alegre. Whereas the Porto Alegre forums were more "European" in their intellectualism and in their focus on political analysis and discourse, this year's meeting will be remembered for the lively and colorful demonstrations and marches that wound their way through the grounds of the forum throughout the 6-day event.

\footnotetext{
${ }^{1}$ I was only able to attend the first (2001) meeting of the World Social Forum and was not in Mumbai for this year's meeting. The account I present is based upon media accounts (including activist media sources), conversations with participants in the 2004 Forum, and from electronic discussions on activist list serves.
} 
To a larger extent than in the past, activists from around India and Asia sought to use the WSF to educate international activists and to mobilize international support for their struggles. This points to a particular advantage of the WSF process in helping raise international awareness of the plight of marginalized groups whose voices never reach international forums. Many international activists left India far more informed about the injustices of caste, class, and religious conflicts in India. They certainly would have learned the grievances of the Dalit, or the "untouchables," who were prominent on the Forum's program. They might also have learned how the move of increasing numbers of well-paying information technology jobs from the U.S. and Europe to India affects Indian workers. The Mumbai forum provided an opportunity for Indian hosts to honor a delegation from Pakistan and to expand Hindu-Muslim dialogue. For their part, by interacting with a community of transnational activists well versed in the values of participatory democracy, Indian activists (and the Brazilians before them) were forced to be sensitive to some of their own exclusionary practices.

A practice that characterizes all WSF meetings is that organizers work to organize series of linked sessions addressing a particular theme or program of action. Many groups use the WSF as an opportunity to coordinate international action on a particular goal, such as resisting trade in genetically altered foods, mobilizing against global and regional trade talks, or protecting small-scale farmers. This year's WSF saw the convening of a "General Assembly of the Global Antiwar Movement." It provided spaces for antiwar activists around the world to exchange notes on their organizing experiences and to strategize for the future. The Assembly consisted overwhelmingly of activists from outside the U.S., and the initial call for the assembly came during the Asian Social Forum in November 2003 from about 50 (mostly Asian) organizations from 17 countries.

This is not to say that discussion of "imperialism" in general and the U.S. occupation of Iraq in particular was limited to this smaller assembly. The subject was among the central themes of the meeting, and it was prominent in key plenary sessions. Reports suggest that the opposition to the Iraq war was a priority for many groups, and proposals to organize a March 20 "global day of action" and to take action against companies that are profiteering from the war are among the very few concrete actions on which many if not most participants could agree to take action.

Reporting on the General Assembly of the Global Antiwar Movement, Tom Hayden -a prominent leader in the U.S. student and anti-war movement in the 1960s-- observed concrete illustrations of transnational solidarity (alternet.org). He noted a deliberate emphasis on the need to curb more radical critiques of the war in order to expand the base of opposition to the U.S. antiwar effort. We need "'less sloganeering, more reachingout," in the words of an activist from the Middle East. Numerous speakers urged organizers to conduct their protests in ways that would help support the peace movement in the United States. Hayden quoted a Costa Rican delegate who argued, "We must coordinate with American movements, not let ourselves be seen as anti-American, and not be seen as violent." In another panel Achin Vanaik, a prominent Indian nuclear weapons expert and founder of the Coalition for Nuclear Disarmament and Peace called for international solidarity in the antiwar movement: 
To beat U.S. imperialism we must help struggles and resistances develop within each country. And we must recognise and explain to the people that there is a direct connection between U.S. empire-building, war and globalisation. We are trying to change the relationships between the forces against the United States [policy] and thus strengthen and unite the move[ment].

Of course, at the antiwar assembly as well as in other sessions of the WSF, speakers emphasized the connections between economic globalization, traditional forms of imperialism, militarism, and U.S. unilateralism. Novelist-activist Arundahti Roy urged activists to use tactics familiar to those resisting corporate globalization to oppose the U.S. occupation of Iraq by "closing down" the offices of corporations profiting from the war in every country where they operate.

This year the WSF was a place where citizens from outside the U.S. could voice their concerns about the dangers of U.S. unilateralism to a multi-national if not global audience. In the words of Federico Mayor Zaragoza, former director-general of UNESCO, "We must state it clearly. We must say to President Bush that we do not agree with the way he controls the world. We must tell him that he has to govern with his mind, not with might." Numerous activists complained that, despite their unprecedented numbers, world leaders continued to ignore massive popular protests like the WSF and last year's antiwar protests. How, they asked each other, can we get our voices heard? The WSF provided the space for transnational dialogue on this particularly urgent question of what should be done. Such transnational strategic dialogue seems particularly relevant in an age when a lone superpower can pursue unilateral interests despite nearly universal opposition. But like many previous struggles, the WSF must confront the difficulties of maintaining an internally democratic structure while it seeks to promote effectively a more democratic international order (see Polletta 2002).

\section{Challenges Ahead}

Unity amid diversity has its limits, and the move to Mumbai exposed numerous fault lines in the WSF process. Compared to earlier forums, more time was spent in Mumbai offering critical reflection on the WSF process and on ways to respond to the limitations that were becoming increasingly contentious.

Many activists complained that the forum devotes extensive energies to facilitating this enormous gathering but its refusal to make any declarations or joint programs for action is a wasted opportunity. One of the Forum's founders, Bernard Cassen, argued that the WSF has reached the limit for how useful the current template can be. He wants to see a "Porto Alegre Consensus" to challenge if not replace the Washington Consensus. That would require a capacity to make collective statements and take collective actions.

Democracy poses challenges even for very small and homogenous groups. The WSF attempt at fostering participatory democracy, then, is heroic. But activists have identified a number of tendencies in the WSF that inhibit democracy, and some are considering how to address these in future forums. The main problem is the "giganticism" of the 
forum. Besides the logistical dilemmas of organizing a meeting of 100,000 or more activists (in group that consciously rejects centralized organizational structures), few locales have facilities that can effectively accommodate such a large group. Despite admirable efforts by the Indian organizing committee, the facilities in Mumbai limited opportunities for networking, and participants in sessions had to compete with the noise of the endless marches circulating outside the meeting spaces.

Such large meetings are also very daunting for many of the world's activists - many of whom have never flown on an airplane or attended formally structured mass meetings. Those lacking experience in these kinds of meetings are inevitably at a disadvantage, and they often find it difficult to contribute to discussions, even if they have facility with the working languages. Although activists attempt to remain sensitive to the differences in participants' experiences, this is not always enough to insure equitable access to the meetings.

More problematic, however, is the limited time or space available for public debate or dialogue, as much of the program was filled with formal panels that left little room for audience response. Some complained of the "talking head" phenomena, whereby prominent intellectuals or members of parties or governments offered "long winded exposés on the evils of neoliberalism," occupying considerable space on the program but offering little in the way of concrete ideas for action. However, now that their help in articulating a critique of neoliberalism is no longer so central, a number of the movement's prominent intellectuals chose to move into the background to make space for new voices to emerge.

Another important debate is how inclusive the Forum must be. If it is a place for civil society actors, should political parties or members of governments be invited to participate? Is funding from corporate or other questionable sources acceptable? Indian organizers opted to reject funding from the Ford Foundation (which funded previous Forums but which was rejected this year for its role in the green revolution), the Department for International Development of the British Government, the European Union and the MacArthur Foundation.

\section{A Hundred Flowers Bloom, but the Maoists aren't Invited}

If the Forum values inclusion, why does it insist on what activist Jai Sen (2003) calls "organizational fundamentalism," that is, limiting formal delegate status to organizations while excluding individuals? And to what extent must participants be required to accept the key principles of the forum even when they may not have developed clear positions on these questions (e.g., opposition to neoliberalism and rejection of violent strategies for social change). Splits over these principles fueled the "Mumbai Resistance," a parallel meeting of more radical activists who argued that the WSF position offers too limited a critique of capitalism. More than 300 groups participated in the parallel forum, and among these were groups that espouse violence as a political tactic.

This antagonism reflects what IC member Roberto Savio refers to the tensions between the first and second "generations" of global civil society. While the first generation 
developed through more cooperative relationships with global institutions, the second generation has adopted a more confrontational approach. While there certainly is some polemicism and sectarianism at work in this all-too-familiar radical-moderate rift, the Mumbai Resistance does raise some important challenges for the WSF, and its message merits attention from those hoping to strengthen the movement. First, it criticized the Indian organizing committee for being overwhelmingly comprised of professional NGOs - many of which had funding from the World Bank and other international sources with ties to global capital. At the same time, they argued that large, popular grassroots movements were excluded from the meetings planning and program. Second, the Mumbai Resistance warned against cooptation of the Forum by those promoting "globalization with a human face," including Joseph Stiglitz, the former chief economist of the World Bank (now a prominent critic), who was among the plenary speakers on this year's program. Finally, they demanded more attention to collective action.

Another complaint raised by several organizers is that the WSF has not taken sufficient advantage of the Internet as an organizing tool. Even experienced organizers have difficulties identifying counterparts in other countries with whom to organize workshops. And navigating the large meeting sites required for this kind of meeting can be a challenge even for those who speak the local language. But clearly more can be done to help activists identify others working on similar issues and enable more preparatory work before the WSF sessions. Ideas for developing a mechanism for selecting a limited number of delegates to the WSF are being circulated, as are procedures for conducting referenda that would allow the Forum to adopt common positions and action plans.

\section{The WSF as a Global Public Sphere}

The WSF not only fosters networking among activists from different places, it also plays a critical role in supporting what might be called a global public sphere. Democracy requires public spaces for the articulation of different interests and visions of desirable futures. Nobel laureate Amartya Sen (2000) argues, "democracy helps the formation of values and priorities through open public discussion and responsible participation. The citizens are given the opportunity to interact with each other--comparing notes, debating issues and understanding one another." Without a global public sphere, there can be no shared values or preferences, and governments lack accountability for actions outside their borders. Moreover, they lack any effective public input from citizens on international policy.

Not only is the WSF a foundation for a more democratic global polity, but it also provides routinized contact among the countless individuals and organizations working to address common grievances against globalized capitalist structures. This contact is essential for helping activists compare analyses and coordinate strategies, but it is also indispensable as a means of reaffirming a shared commitment to and vision of "another world," when their day-to-day struggles dampen such hope. Isolated groups lack information and creative input needed to innovate and adapt their strategies. In the face of repression, exclusion, and ignorance, this transnational solidarity helps energize those who challenge the structures of global capital. While many activists will never have the chance to attend the main WSF meeting, the Forum and its regional and local 
counterparts serve as focal points that dramatize the unity among diverse local struggles and encourage coordination among activists working at local, national, and transnational levels.

Despite its limitations, the WSF is undoubtedly the most globally inclusive initiative for fostering transnational civil society. Given the absence of other institutional arrangements to foster accountability, transparency and participation in global politics, this democratic initiative should be encouraged. Governments and other defenders of the status quo raise countless justifications for limiting popular input into global institutions. But evidence of a dangerous lack of legitimacy in global institutions is mounting, and more political elites are calling for efforts to address this "democratic deficit." Amartya Sen (2000) notes that "A country does not have to be deemed fit for democracy; rather, it has to become fit through democracy." The same should hold for a global polity.

Expanded participation in the WSF and its regional/local counterparts would nurture experiences and skills that would make a more democratic global order feasible. Thus, those who hope for a more democratic world must work to increase the transparency of global institutions and to strengthen the possibilities for transnational civic engagement. The WSF provides a promising starting point.

\section{Sources}

Benjamin, Medea. 2004. "10 Good Things About a Bad Year” Alternet. January 1. At http://www.alternet.org/story.html?StoryID=17471 accessed 8 April 2004

August Nimtz. 2002. "Marx and Engels: The Prototypical Transnational Actors." Pp. 245-268 in Restructuring World Politics: The Power of Transnational Agency and Norms, edited by S. Khagram, J. Riker, and K. Sikkink. Minneapolis: University of Minnesota Press.

Francesca Poletta. 2002. Freedom is an Endless Meeting. Chicago: University of Chicago Press.

Amartya Sen. "Democracy, the Only Way out of Poverty" New Perspectives Quarterly 17 no1 28-30 Winter 2000.

Jai Sen, Anita Anand, Arturo Escobar, and Peter Waterman, eds. 2003. Challenging Empires: the World Social Forum. Third World Institute: Available in Pdf format at www.choike.org

\section{Reports on World Social Forum}

www.forumsocialmundial.br (Porto Alegre World Social Forum)

www.India.indymedia.org (Activist Indy media coverage of Mumbai WSF)

www.ipsnews.net (Terra Viva -daily coverage of WSF)

www.nadir.org (Mumbai Resistance)

Www.Opendemocracy.net (Independent media coverage \& analysis) 
WwW.Alternet.org (Independent media coverage \& analysis) 